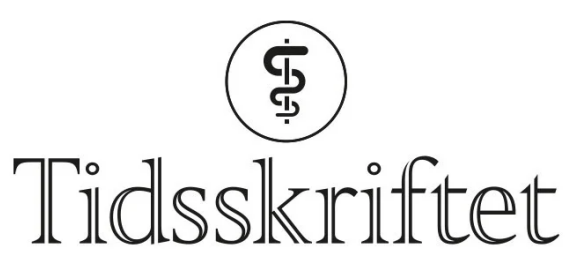

DEN NORSKE LEGEFORENING

\title{
Vaksine mot vaksineskepsis?
}

FRA REDAKTØREN

\section{RAGNHILD ØRSTAVIK}

ragnhild.orstavik@tidsskriftet.no

Ragnhild Ørstavik er assisterende sjefredaktør i Tidsskriftet. Hun er dr.med. og har en bistilling som seniorforsker ved Folkehelseinstituttet.

\section{Vitenskapen har på kort tid generert effektive vaksiner mot covid-19, men ennå ikke svart fullt ut på spørsmålet om hvordan vi kan få flest mulig til å ta vaksinen.}

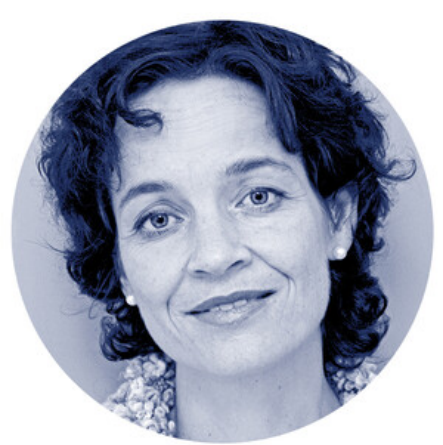

Foto: Einar Nilsen

En morgen i 1962 satt Roald Dahl ved sengen til datteren sin, Olivia. Hun var på bedringens vei etter en meslinginfeksjon. «Hvordan føler du deg?» spurte han. «Trett», svarte hun. Neste morgen var hun død (1) .

24 år senere skrev den da verdensberømte barnebokforfatteren et brev til sine lokale helsemyndigheter, der han ba foreldre om å benytte vaksinen som i mellomtiden var blitt tilgjengelig (1). Dahl spiller på følelser, både ved å beskrive Olivias sykdom og ved å kalle foreldre som ikke vaksinerte barna, for kriminelle. Men han spiller også på en slags fornuft: Ifølge forfatteren av Charlie og sjokoladefabrikken var sannsynligheten for at barnet skulle få alvorlige bivirkninger av vaksinen, lavere enn for at det ble kvalt av en sjokoladeplate $(\mathbf{1}, \underline{2})$.

Hva slags effekt har egentlig slike virkemidler? Nå, tre år etter at WHO erklærte vaksineskepsis som én av verdens ti viktigste helsetrusler, og snart to år inn i covid-19pandemien, er kunnskapen om hvordan man kan motvirke vaksinemotstand, fremdeles begrenset, og ekspertene fortsatt uenige (2). Det meste tyder på at skremsler ikke virker (3= 5). Tvert imot kan det ha motsatt effekt: I en studie fra 2014 ble foreldre som fikk se bilder av syke barn med meslinger, mer overbevist om at vaksinen kunne gi autisme enn før de så bildene (ㅁ) . Frykten kanaliseres kanskje mot det foreldrene kjenner (autisme), i stedet for 
en sykdom de aldri har sett (meslinger) (2,4.4). Å få folk til å skamme seg (kalle dem kriminelle) fører til at de går i forsvar fremfor å endre oppfatning (3.5). Fakta, som sjokoladeeksempelet, bringer oss et stykke på vei, men neppe helt frem (3-5). Forskningen omkring vaksinevillighet er nemlig full av overraskelser: I en ny studie over foreldres holdninger til HPV-vaksine viste det seg at mødre som selv hadde hatt livmorhalskreft, ikke i større grad enn andre mødre ville gi barna vaksinen (7.). Dermed er det kanskje ikke så overraskende at selv syke familiemedlemmer ikke er nok til å overbevise folk om å ta vaksine mot covid-19 (ㅁ).

\section{«Det meste tyder på at skremsler ikke virker»}

Årsakene til å takke nei til vaksine kan grovt sett deles i tre grupper: Bekymring for bivirkninger, feilaktige oppfatninger om hvordan vaksinen virker, og tiltro til konspirasjonsteorier (som at sykdommen er oppspinn, eller at vaksinen utelukkende er oppfunnet for å tjene penger) (9.). Den siste gruppen er vanskeligst å vende, også under den pågående pandemien. Uansett hva de hører, vil de oppfatte det som en bekreftelse på kjernebudskapet til konspirasjonsteoretikerne: at vaksinen er skadelig, at covid-19 er ufarlig, og at myndighetene ikke er til å stole på (10 $)$. Bak budskapet ligger velorganiserte grupper godt hjulpet av sosiale medier (므). Og bak tolkningen av det andre oppfatter som logikk og fornuft, ligger psykologiske mekanismer som er felles hos oss alle: Når vi er overbevist om noe, tenderer vi til å søke bekreftelse på at vi har rett, fremfor å være nysgjerrige på alternativene.

Men den største gruppen av skeptikerne er usikre, bekymrete, eller vil vente og se $(3, \underline{4}, \underline{11})$. Det er denne gruppen vi må forsøke å nå - systematisk og tilpasset en heterogen målgruppe. Helsearbeidere kan bruke motiverende intervju, der man stiller åpne spørsmål og forsøker å finne ut av hva den usikre er redd for (9.). Og dryppe små doser av argumentasjon som motsier konspirasjonsteoretikernes budskap, som en slags vaksine mot informasjon folk kan få fra andre kilder (3,9).

Alle som til nå har valgt å avstå fra covid-19-vaksine, bør møtes med åpenhet og et stående tilbud om en første dose. Ikke nødvendigvis fordi det er det moralsk riktige, men fordi det er slik vi har størst mulighet for å lykkes.

\section{LITTERATUR}

1. Roald Dahl. Death of Olivia. November 1962 - death of Roald Dahl's daughter Olivia. https://www.roalddahl.com/roald-dahl/timeline/196os/november-1962 Lest 27.12.2021

2. Kupferschmidt K. The science of persuasion. Science 2017; 356:366-9. [PubMed][CrossRef]

3. Olson O, Berry C, Kumar N. Addressing Parental Vaccine Hesitancy towards Childhood Vaccines in the United States: A Systematic Literature Review of Communication Interventions and Strategies. Vaccines (Basel) 2020; 8: 590. [PubMed][CrossRef]

4. Rosenbaum L, Malina D. Escaping Catch-22 - Overcoming Covid Vaccine Hesitancy. N Engl J Med 2021; $384: 1367-71$. [CrossRef]

5. Guide to COVID-19 vaccine communications. A practitioner's guide to the principles of COVID-19 vaccine communications. University of Florida 2021. https://covid19vaccinescommunicationprinciples.org/the-principles/emotions/ Lest 29.12.2021

6. Nyhan B, Reifler J, Richey S et al. Effective messages in vaccine promotion: a randomized trial. Pediatrics 2014; 133: e835-42. [PubMed][CrossRef]

7. Worsham CM, Woo J, Zimerman A et al. Association of Maternal Cervical Disease With Human Papillomavirus Vaccination Among Offspring. JAMA Netw Open 2021; 4: e2134566. [PubMed] [CrossRef]

8. Jena $\mathrm{AB}$, Worsham CM. Facts alone aren't going to win over the unvaccinated. This might. New York Times 21.12.2021 https://www.nytimes.com/2021/12/21/opinion/vaccine-hesitancy-covid-omicron.html? referringSource=articleShare Lest 27.12.202 
9. Gorman JM, Scales DA, Gorman SE. Expert opinion in mental disorder: Why is acceptance of the COVID-19 vaccines so problematic? Pers Med Psychiatry 2021; 25-26: 100072. [CrossRef]

10. Ahmed I. Dismantling the anti-vaxx industry. Nat Med 2021; 27:366. [PubMed][CrossRef]

11. Opinion. Hvem er de som ikke vil ta vaksine? https://opinion.no/2021/og/hvem-er-de-som-ikke-vilta-vaksine/ Lest 29.12.2021

Publisert: 10. januar 2022. Tidsskr Nor Legeforen. DOI: 10.4045/tidsskr.22.0002

(C) Tidsskrift for Den norske legeforening 2023. Lastet ned fra tidsskriftet.no 26. april 2023. 